\title{
The delayed mortality of discarded sea bream (Sparus aurata Linnaeus, 1758) in trawl simulation: an experimental appraisal
}

\section{Deneysel yaklaşımla trol simülasyonunda ıskarta edilen çipurada (Sparus aurata Linnaeus, 1758) gecikmiş ölüm}

\author{
Aydın Demirci ${ }^{*}$ (D) Emrah Şimşek ${ }^{1}$ (D) \\ ${ }^{1}$ Iskenderun Technical University, Marine Sciences and Technology Faculty, Department of Marine Technologies, 31200, Iskenderun, Hatay/Turkey \\ *Corresponding author: aydin.demirci@iste.edu.tr
}

Received date: 21.02 .2018

Accepted date: 04.04 .2018

How to cite this paper:
Demirci, A. \& Şimşek, E. (2018). The delayed mortality of discarded sea bream (Sparus aurata Linnaeus, 1758) in trawl simulation: an experimental appraisal.
Ege Journal of Fisheries and Aquatic Sciences, 35(3), 237-241. DOl:10.12714/egejfas.2018.35.3.02

Abstract: This study aims to bring to light behavioral impairment and the delayed mortality of discards below legal catch rate in a simulated trawl operation. Behavioral impairment of 126 fish in the aftermath of trawling operation was tested in two different methods through observing their reflexes. In the first method, all the fish in the tank was compared with the control groups on account of their responds to different stimulants, while in the second method, reflex measurement was individually carried out. Reflexes from these two processes were taken as the extent of behavioral impairment and a relation with delayed mortality was established. A considerable number of fatalities among those returning to the water came about within 24 hours. There was a proportional connection between behavioral impairment and delayed mortality. However high the behavioral impairment might be, the mortality rate remained at a certain proportion. A considerable number of fish survived under confined medium in the laboratory tanks.

Keywords: Reflex, behavioral impairment, trawl simulation, discard, delayed mortality

Öz: Bu çalışmanın amacı sanal bir trol operasyonu gerçekleştirerek yasal yakalama boyunun altında olan ıskartaların davranış bozukluğu ile gecikmiş ölüm oranı arasındaki ilişkiyi açıklamaktır. Deneysel trol çekimleri sonrasında 120 balığın davranış bozukluğu, farklı uyarıcılara karşı reflekslerin gözlemi yoluyla iki farklı metotla test edilmiştir. İlk metotta gözlem tüm balıkların farklı uyarıcılara karşı reflekslerin gözlemi toplu halde kontrol grupları ile karşılaştırıırken ikinci metotta refleks testleri bireysel olarak yapılmıştır. İki metotta da davranış bozukluğunun derecesi olarak alınan refleksler ile gecikmiş ölüm arasında bir ilişki bulunmuştur. Denize canlı dönen bireylerdeki ölümlerin önemli bir kısmı yaklaşık 24 saat sonra gerçekleşmektedir. Davranış bozukluğu ile gecikmiş ölüm arasında doğrusal ilişki bulunmuştur fakat davranış bozukluğu ne kadar yüksek olursa olsun ölüm belli bir oranda kalmaktadır. Canlıların önemli bir kısmı laboratuvar ortamındaki kısıtlanan tanklarda canlığını sürdürmüştür.

Anahtar kelimeler: Refleks, davranış bozukluğu, trol simülasyonu, ıskarta, gecikmiş ölüm

\section{INTRODUCTION}

Sea resources for exploitable aquatic organisms are presently under heavy strain by overexploitation (Anonymous, 2002). In addition to the over use of resources, the "discards" are a case in point. Annual global amount of discards was cited by Alverson et al. in 1994, as 27 million tons while Kelleher estimated it in 2005 as 7.3 million tons.

Though referred to as unfavorable way of fishing due to its nonselective nature, trawling is still one of the most common methods across the world since it has no alternative from technical, sociological and economical aspects. Although this kind of fishing exhibits certain differences according to locality and season, it still has rather high discard ratio (Anonymous, 2002). Market conditions in traditional trawling change in discarded species and/or their discard ratios. It is rather important to be selective for such species before taking on board without letting them into the trawl net or allow them to escape from the net if caught. Yet, in spite of efforts in this direction such discard species in remarkable amount are taken on board and disposed to sea after catch.

Delayed mortality events result from physical injure, infection, wounds due to prey-predator relation and acute physiologic stress all arising from behavioral impairment (Davis, 2002; Davis and Parker, 2004; Şimşek, 2012; Demirci et al., 2012). Although tried to be controlled with environmental conditions and distribution of species as well as with their interaction, delayed mortality factors are still not accurately understood (Davis, 2002). Studies on the impact of stress of fish are important to understand and control the ecological 
impact of discard mortalities and other natural as well as human induced stresses on exploited sea ecosystem.

In order to measure the delayed mortality rate, several approaches have been employed so far (Davis, 2002, 2005, 2007, 2009). Direct method for estimation of delayed mortality is to observe discard and survival rate in tanks on the board. (Schreck et al., 1997; Saygu and Deval, 2014; Şimşek and Demirci, 2016). There exist certain deaths which remain unobserved. These deaths or mortalities can occur long time after the trawling operation and they are called delayed mortality (Chopin and Arimoto, 1995; Davis, 2002; Benoît et al., 2012; Benoît et al., 2013; Demirci et al., 2012; Şimşek, 2012; Şimşek and Demirci, 2016). An approach would be to develop the studies carried out in laboratory medium with such measurement criteria including injuries, physiology and behavioral observations will help us find out reasons for unknown deaths. In addition to being an ecologic measurement, behavioral impairment could be due to several stress resources including being discarded (Beitinger, 1990; Schreck et al., 1997; Davis and Parker, 2004).

In this study, observations were taken as basis with a view to develop methods and application for use in fisheries management for Eastern Mediterranean. Behavioral impairment in fish exposed to trawling simulation was evaluated through two different approach. In these two approaches, the fish, subjected to experimental trawl tired, were examined behavior impairment. In the first approach, individual reflex tests were performed of fish. In the second approach, the fish groups were evaluated behavior.

\section{MATERIALS AND METHODS}

Experiments were conducted at Fish Behaviour Laboratory from January to March 2012. 126 Sea bream (Sparus aurata) were used in this experiment was provided from a local fish farm. All of the individuals included in the study were males with an average length of $13.7 \mathrm{~cm}$, ranging from10 to $15.4 \mathrm{~cm}$ lengths. Length of legal catch size of sea bream is $20 \mathrm{~cm}$ in the fishing area in Turkey (Anonymous, 2016).

\section{Trawling simulation system}

The simulation system consist of rotating in a tank of water in the tank is $2.5 \mathrm{~m}$ in diameter creates two trawl bag. Rotational power is provided by a quiet and powerful electric motor. It was carried out rotation with speed control unit under control. In the study 126 fish were used for all tests and each simulating trawl hauling taken 2 hours in this system. 87 of these fish were used for total behavioral impairment of fish shoals in 7 simulating trawl hauling. 39 of these fish were used for individual behavioral impairment in 10 simulating trawl hauling.

\section{Subjecting fish to simulated trawling operation}

Tiring process: In this phase fish were subjected to simulated trawling operation so that they are tired. Trawling speed was $7 \mathrm{rpm}$ and $1.8 \mathrm{knot}$.
Exposing to air: Upon hauling the trawl net from water in trawling operations, fish are left exposed to the effect of air depending on several variables including fish selecting work on board, relaying the trawl net and other time consuming variables. In this study, fish subjected to tiring process for 2 hours were all exposed to air for 5 minutes before being put in the observation tanks.

\section{Observing total behavioral impairment of fish shoals}

Shoals of fish were put into the observation tank so that they could be compared with the control group. In this observation tank, behavioral impairments occurring due to exhaustion were observed at the end of $5 \mathrm{~min}, 10 \mathrm{~min}, 20 \mathrm{~min}$, $40 \mathrm{~min}, 60 \mathrm{~min}, 90 \mathrm{~min}, 120 \mathrm{~min}$ and 24 hours. In all the observations ranging from $5 \mathrm{~min}$ to $24 \mathrm{~h}$, general behavioral change, and their responses to sound, sight and sense of feeling external contacts were all taken into account. The correlation between the mortality rates and reflex impairment values obtained from the 8 different times after trawling simulation.

Swimming ability: There was difference between the general condition of the control group and that of the fish tired during the trawling simulation, which can be attributed to their co-ordination in the shoal, in the other words to their behaviors resulting from their awareness of each other. A classification from 1 to 4 was based on the number of fish with different behaviors and the degree of difference. In the experiment the fish were observed on the basis of the peculiarities and the speed of their swimming and grouping (Fig. 1).

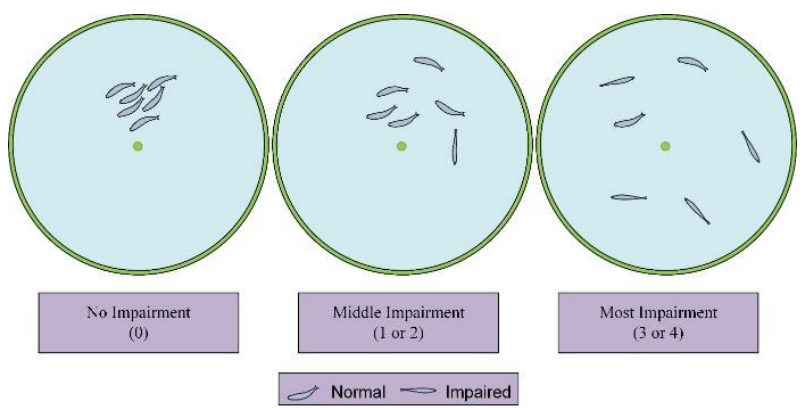

Figure 1. Monitoring tanks after trawling simulation to observe the reflex impairment (The fish exposed to trawl simulating tired were placed on the observation tank in shoals and were scored scales by following the tank from a distance according to the figure)

Sound: The sensitiveness of fish in the control group to sound was compared with that of the fish exhausted in the trawling operation. Also, the number of fish responding to an external impact on the tank was assessed both in the control and test groups.

Vision: An effort was made to identify the different responses to action made on the surface.

Touching: An easy and decisive method which leads to a conclusive assessment in the observation. If you manage to touch the fish, in other words, if it doesn't swim away but seems 
to be uncaring, this denotes behavioral impairment. In the experiment, effort was made to approach the fish with a plastic stick and their reflect was evaluated.

\section{Determining individual behavioral impairment}

According to Davis (2009), the response by a fish to an external impact is an indication of the intensity resistance to increasing stress factors. The starting time of the spontaneous response to the external force is significant. Here in this study, four distinct responses were counted. The responses under question were measured with the help of a holder and a nylon probe $5 \mathrm{~min}, 30 \mathrm{~min}$ and $60 \mathrm{~min}$ after a 2 hour-trawling simulation including $5 \mathrm{~min}$ air exposure.

Gill movement: The movement of gills is important for the breathing of fish. Gill flaps were opened with a nylon probe of 3 $\mathrm{mm}$ diameter and were then closed before the reaction could be observed and recorded.

Movement of mouth: When the mouth was in closed position, it was opened with a probe and then closed. Here the adaptation of the fish's movement to gills was observed.

Eye response: One of the essential stages in individual examine was the condition of eyes after trawl tiring simulation. Here was to observe visually the change in eye diameters, which is considered to determine stress factor. That's why eye diameters were followed up after tiring process and compared with those of the control group.
Throat reflex: Throat response was observed with a probe.

General body reflex: Upon positioning the fish on the observation kit in away which would not harm it, every changing movement on the body was observed with a view to make an assessment. Unlike other tests, the fish were not subjected to an additional process, but was only observed.

Assessment of the data: All the findings were evaluated with MS Office Excel Program using arithmetical mean and simple regression.

\section{RESULTS AND DISCUSSION}

Given in Table 1 are the number of fish employed in 7 valid trawling operations as well as mortality ratio within 48 hours after hauling. The fact that most of the deaths occurred 24 hours after the hauling appears to be in parallel with similar studies (Saygu and Deval, 2014; Şimşek and Demirci, 2016).

Behavioral impairment observed are given in Table 2 according to duration after hauling. Here, score ' 4 ' means maximum disorder and ' 0 ' is means normal behavior. According to this visual index obtained from preliminary studies, a partial improvement occurs in time in behaviors and reflex of the sea bream subjected to trawling tiring and exposed to air, however, complete normalization should not be expected.

Table 1. The number and the mortality rates of samples

\begin{tabular}{|c|c|c|c|c|c|c|}
\hline \multirow{2}{*}{ Number of Haul } & \multicolumn{2}{|c|}{$24 \mathrm{hrs}$} & \multicolumn{2}{|c|}{$48 \mathrm{hrs}$} & \multicolumn{2}{|c|}{ Mortality Rate } \\
\hline & Alive & Death & Alive & Death & Delayed & Acute \\
\hline 1 & 13 & 0 & 10 & 3 & 0.30 & 0.00 \\
\hline 2 & 11 & 1 & 9 & 2 & 0.22 & 0.09 \\
\hline 3 & 12 & 1 & 9 & 3 & 0.38 & 0.08 \\
\hline 4 & 11 & 1 & 7 & 4 & 0.50 & 0.09 \\
\hline 5 & 12 & 1 & 9 & 3 & 0.38 & 0.08 \\
\hline 6 & 12 & 1 & 10 & 2 & 0.18 & 0.08 \\
\hline 7 & 10 & 1 & 8 & 2 & 0.22 & 0.10 \\
\hline
\end{tabular}

Table 2. Assessment of general reflex impairment depending on time

\begin{tabular}{ccccc}
\hline $\begin{array}{c}\text { Duration } \\
\text { (Minute) }\end{array}$ & Swimming & Hearing & Visual & Touch \\
\hline 5 & 4 & 4 & 4 & 4 \\
10 & 3.75 & 4 & 3.75 & 4 \\
20 & 3.5 & 4 & 3.5 & 3.75 \\
40 & 3.5 & 4 & 3.25 & 3.75 \\
60 & 3.25 & 3.75 & 3.25 & 3.25 \\
90 & 3.25 & 3.25 & 3.25 & 3.25 \\
\hline 120 & 3.25 & 3 & 3 & 2.75 \\
\hline
\end{tabular}

It was evaluated according to Figure 1 by comparison with a control group as a test group; Swimming; there is not any intervention, only observation. Hearing; the responses of fish when after the tank outside shot. Visual; the response when any object is seen. Touch; the response of fish when any object is touch. 
It is known that deaths following haulage occur more as delayed mortality than acute ones. This period and ratio of the delays exhibit difference according to particular species (Davis and Olla, 2002; Davis and Parker, 2004; Davis and Ottomar, 2006).

The response by a fish to stimulant is an indication for the intensity of the resistance of the fish to external stress contributing factors (Davis, 2009). Regarding any stimulating event, the starting time of the spontaneous response by the fish to this event is of importance. If the response starts in no time with the approach of the probe, we can regard this behavior as normal. Yet, if the fish does not seem to be disturbed by the probe, without showing any reflex, we say it has a behavioral impairment (Davis, 2009). Sea bream, employed in this study exhibited a rather high degree of behavioral impairment, however, $50 \%$ of the fish exhibited improvement to the normal conditions within 48 hours. Later on these fish, kept in the tank, displayed a total improvement in four days, though this was not included in the assessment.

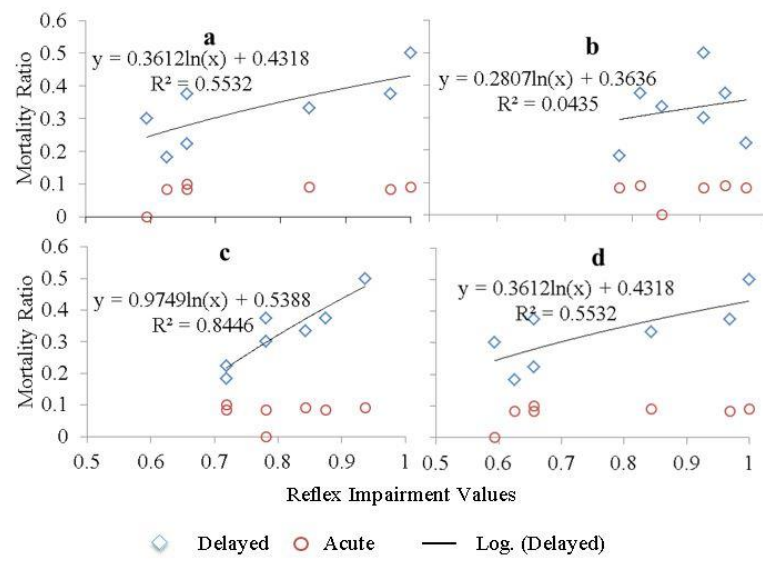

Figure 2. Correlation between mortalities and reflex impairment values (a; swimming, b; hearing, c; visual, d; touch)

Although acute mortalities occurred in all trawling simulations except in one, these mortalities were rather low in ratio. Nonetheless, there were so called delayed mortalities occurring within 24 hours following the trawling simulations. Submitted below are the values of different reflex impairments observed (Fig. 2). In figure 3 all reflex impairment values are given in general mean.

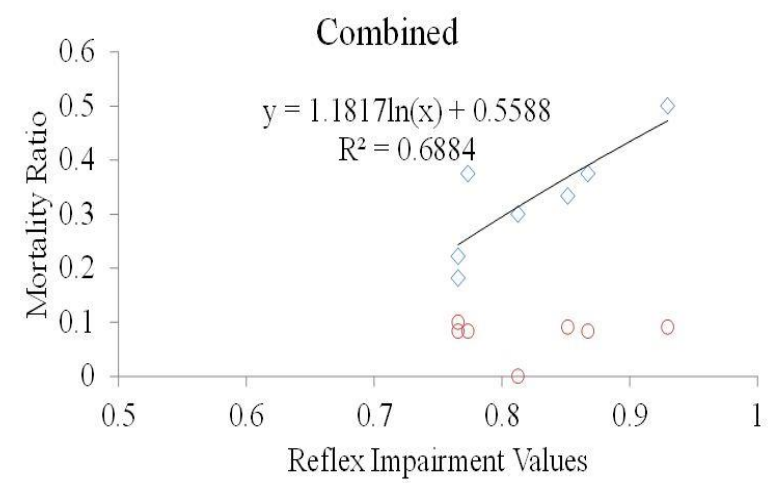

$\checkmark$ Delayed $\bigcirc$ Acute - Log. (Delayed)

Figure 3. Correlation between mortality ratios and combined reflex impairments

According to these results, values for impaired vision and swimming reflex may be compared to mortality rates, however, in practice it is easier to identify any reflex impairment with the help of touching with a probe. On the other hand, with a fish having healthy reflex, it is not even possible to approach a fish with healthy reflex, let alone touch it. Although it was clear in practice that the fish exhibited normal reflex, findings are considered not to have displayed appropriate numerical data for use in assessment. Yet, the relation gains significance when four different observed values are used together.

The relation between the mortality rate and reflex impairment is expected to be rather different than linear one, because no matter how high is the reflex impairment, mortality rate ceases to increase at a certain point, stabilizing there. Actually, due to insufficient control of the conditions during the experiment, it is felt that distinctions between trawling simulations were inadequate. Minute daily fluctuations in water and air temperature could be put in the distinction list. It is considered that more accurate studies be planned for the sake of better control.

For all that, the presence of a particular relation means that the very method could be useable. The fact that reflex impairment values depend on personal observations leads to unwelcome results with that method. With a view to reach less unfavorable results, the higher degree of experience of the researcher plays a vital role. Moreover, it would be preferable to use statistical methods other than those numerical ones based on observations.

Table 3. Individual reflex impairment depending on time

\begin{tabular}{ccccccc}
\hline $\begin{array}{c}\text { Duration } \\
\text { (Minute) }\end{array}$ & $\begin{array}{c}\text { Number } \\
\text { of Fish }\end{array}$ & GBR & VR & MM & GR & TR \\
\hline 5 & 16 & 0.4 & 0.8 & 0.3 & 0.4 & 0.6 \\
30 & 13 & 0.5 & 0.7 & 0.0 & 0.3 & 0.5 \\
60 & 10 & 0.6 & 0.8 & 0.3 & 0.2 & 0.4 \\
\hline
\end{tabular}

"Each fish's reflex was assessed individually" GBR: General Body Reflex VR: Visual Response, MM: Mouth Movement, GR: Gill Response, TR: Throat Reflex


Assessment of individual reflex impairment given in table 3 was based on that by Davis $(2007 ; 2009)$. Though a partial improvement depending on time was observed with the Sea bream in this trawling simulation carried out with these variables, the time elapsing for the improvement was rather too long. To this end, 10 trawling simulation were performed in groups of six fish.

As the reflex impairment obtained from this method is more related with the very response rather than the observations the assessment is considered more accurate. On the other hand, a second intervention to each fish for individual test is regarded potential acute stressor, for each fish is to be captured in the tank so that its response can be studied out of water within approx. 30 seconds. Following this second test most of the fish died. That is why the relationship between the reflex impairment obtained here and mortality rates was not investigated.

\section{REFERENCES}

Alverson, D.L., Freeberg, M.H., Murawski, S.A. \& Pope, J.G. (1994). A globa assessment of fisheries bycatch and discards. Fisheries Technical Paper, 339.

Anonymous, (2002). The State of World Fisheries and Aquaculture. Rome: $\mathrm{FAO}$

Anonymous, (2016). Republic of Turkey Ministry of Food, Agriculture and Livestock, Notification of regulating commercial fishery (Notification no: 2016/35). (In Turkish)

Beitinger, T.L. (1990). Behavioural reactions for the assessment of stress in fishes. Journal of Great Lakes Research, 16, 495-528. DOI: 10.1016/S0380-1330(90)71443-8

Benoît, H.P., Hurlbut, T., Chassé, J. \& Jonsen, I.D. (2012). Estimating fisheryscale rates of discard mortality using conditional reasoning. Fisheries Research, 125, 318-330. DOI: 10.1016/j.fishres.2011.12.004

Benoît, H.P., Plante, S., Kroiz, M. \& Hurlbut, T. (2013). A comparative analysis of marine fish species susceptibilities to discard mortality: effects of environmental factors, individual traits, and phylogeny. ICES Journal of Marine Science, 70(1), 99-113. DOI: 10.1093/icesjms/fss132

Chopin, F.S. \& Arimoto, T. (1995). The condition of fish escaping from fishing gears - a review. Fisheries Research, 21, 315-327. DOI: 10.1016/0165-7836(94)00301-C

Davis, M.W. \& Olla, B.L. (2002). Mortality of Lingcod Towed in a Net as Related to Fish Length, Seawater Temperature, and Air Exposure: A Laboratory Bycatch Study. North American. Journal of Fisheries Management, 22 1095-1104. DOI: 10.1577/1548-8675(2002)022<1095:MOLTIA>2.0.CO;2

Davis, M.W. \& Ottomar, M.L. (2006). Wounding and reflex impairment may be predictors for mortality in discarded or escaped fish. Fisheries Research 82, 1-6. DOI: 10.1016/j.fishres.2006.09.004

Davis, M.W. \& Parker, S.J. (2004). Fish size and exposure to air: potentia effects on behavioural impairment and mortality rates in discarded sablefish. North American. Journal of Fisheries Management, 24, 518524. DOI: 10.1577/M03-030.1
As a conclusion of the study on the possibility of survival of discarded fish, it was found out that the species under question could sustain its liveliness to some degree under the controlled conditions. When you look into the stages, you will notice that acute mortalities occurred at certain extent even without being caused by a physical wound. However, such mortalities constitute a small part within alive to water occurred 24 hours after they had returned. Yet, this mortality rate does not mean that all of the fish would die however high the behavioral impairment might be. Some of important discarded fish can survive (about $50 \%$ ) even in the worst conditions of the trawl fishery (Şimşek, 2012).

\section{ACKNOWLEDGMENTS}

This study was supported by BAP Foundation of Mustafa Kemal University (Project no: 216). The authors thanks to MKUBAP Foundation.

Davis, M.W. (2002). Key principles for understanding fish bycatch discard mortality. Canadian Journal of Fisheries and Aquatic Sciences, 59, 18341843. DOI: 10.1139/f02-139

Davis, M.W. (2005). Behaviour impairment in captured and released sablefish: ecological consequences and possible substitute measures for delayed discard mortality. Journal of Fish Biology, 66, 254-265. DOI: 10.1111/j.0022-1112.2005.00602.x

Davis, M.W. (2007). Simulated fishing experiments for predicting delayed mortality rates using reflex impairment in restrained fish. Journal of Marine Science, 64, 1535-1542

Davis, M.W. (2009). Fish stress and mortality can be predicted using reflex impairment. Fish and Fisheries, 11, 1-11. DOI: $10.1111 / j .1467-2979.2009 .00331 . x$

Demirci, A., Demirci, S. \& Şimşek, E. 2012. Trol Balıkçılığında Iskartanın Yaşama İhtimali. Balıkçılık ve Akuatik Bilimler Sempozyumu Özet Kitapçığı, 61

Kelleher, K. (2005). Discards in the world's marine fisheries. FAO Fisheries Technical Paper, 470, 131.

Saygu, I. \& Deval, M.C. (2014). The Post-Release Survival of Two Skate Species Discarded by Bottom Trawl Fisheries in Antalya Bay, Eastern Mediterranean. Turkish Journal of Fisheries and Aquatic Science, 14, 1-2.

Schreck, C.B., Olla, B.L. \& Davis, M.W. (1997). Behavioural responses to stress, In Fish Stress and Health in Aquaculture. New York. Cambridge University Press, 145-170.

Şimşek, E. 2012. Trol Balıkçılığında Iskartanın Yaşama İhtimali. Mustafa Kemal Üniversitesi. Fen Bilimleri Enstitüsü Su Ürünleri Anabilim Dalı Yükseklisans Tezi. 28 pp.

Şimşek, E. \& Demirci A. 2016. Analysis of Factors Affecting Life Fate of Groupers after Fishing Operations. Natural and Engineering Sciences, $1(3), 40$ 